\title{
Variability is not uncertainty; mobility is not flexibility: Clarifying concepts in pastoralism studies with evidence from Tajikistan
}

\author{
Kramer Gillin(1)
}

\begin{abstract}
As the "new rangeland paradigm" took shape in the 1990s, climatic variability in pastoral ecosystems was often discussed as "uncertainty", and the essential mobility of pastoral systems was argued to be possible only with flexible land access rights. These context-specific principles have increasingly been globalized in analyses of diverse pastoral systems. While new understandings of the role of uncertainty and flexibility in pastoral systems have been unquestionably beneficial for particular contexts, uncertainty has been problematically embraced as intrinsically central to pastoral systems.

This paper combines a critical review of the literature and field work in Tajikistan's Rasht Valley to bring into clear relief differences between variability and uncertainty, on the one hand, and mobility and flexibility, on the other. This allows us to see that livestock mobility is a strategy to cope with environmental variability in all pastoral contexts. Flexibility, however, is a strategy to cope with environmental uncertainty that is only present in a subset of pastoral contexts. Importantly, flexibility is not a required precondition for mobility. These realizations carry important implications for governance in pastoral settings. Due to the many challenges of building flexibility into property systems, pastoral land governance should be developed by looking for predictability, and efforts to maintain flexibility should be judicious and empirically well-justified.
\end{abstract}

Keywords: Mountain pastoralism, Predictability, Central Asia, Governance, Institutions, Post-Soviet pastoralism

\section{Introduction}

Scholarly understandings of pastoral systems have been underpinned by the concepts of variability, uncertainty, mobility, and flexibility. Despite the centrality of these terms to the pastoralism literature, they have been used inconsistently, imprecisely, and sometimes superfluously. Two separate but related analytical fallacies have emerged as a result. The first is conflating these four distinct terms into two pairs, failing to differentiate between the distinct environmental characteristics of variability and uncertainty (or unpredictability) on the one hand, and also failing to differentiate the two pastoralist responses of mobility and flexibility. The second

Correspondence: kgillin@wisc.edu

Department of Geography, University of Wisconsin-Madison, 550 North Park Street, Madison, WI 53706, USA

\section{Springer Open}

fallacy, which is inevitable if the first fallacy is committed, is the characterization of all pastoral environments as intrinsically unpredictable, and pastoralists' movements and governance systems as intrinsically flexible.

After disentangling these four concepts, we can see that mobility is a response to environmental variability, whereas flexibility is a response to environmental uncertainty. Though some degree of uncertainty is present in every context and livelihood activity, uncertainty as it has been understood and deployed within the pastoralism literature is, in fact, not the most mobilityinfluencing type of variability in all pastoral settings. Therefore, while mobility is intrinsic to pastoralism, the need for flexibility is context-specific and not intrinsic to pastoralism.

(c) The Author(s). 2021 Open Access This article is licensed under a Creative Commons Attribution 4.0 International License, which permits use, sharing, adaptation, distribution and reproduction in any medium or format, as long as you give appropriate credit to the original author(s) and the source, provide a link to the Creative Commons licence, and indicate if changes were made. The images or other third party material in this article are included in the article's Creative Commons licence, unless indicated otherwise in a credit line to the material. If material is not included in the article's Creative Commons licence and your intended use is not permitted by statutory regulation or exceeds the permitted use, you will need to obtain permission directly from the copyright holder. To view a copy of this licence, visit http://creativecommons.org/licenses/by/4.0/. 
In the 1990s, a critical mass of scholars of pastoralism argued that spatiotemporal environmental variability in rangelands necessitated the very flexibility and mobility that was traditionally found in pastoral systems but endangered by pastoral settlement programmes, initiatives of land privatization, or various restrictions on pastoral movements (Niamir-Fuller and Turner 1999). While there had been prior scholarship on the importance of pastoral mobility for adapting to unpredictable environments, in this period, we saw a "convergence of concepts, interpretations, and analyses between the natural and social sciences" (Scoones 1994, 3), which replaced the existing dominant narratives with a new model to understand pastoralism, variously known as "new directions in pastoral development" (Scoones 1994), the "mobility paradigm" (Niamir-Fuller and Turner 1999), the "new rangeland paradigm" (Hiernaux 2000), or the "new pastoral development paradigm" (Turner 2011).

Despite sweeping implications of these labels, the Africa-focussed scholars initially developing and employing these new paradigms advanced their ideas in very empirical and site-specific studies, likely not attempting or intending to describe mobility, rangelands, and pastoral development in every context. Research on mountain pastoralism-which flourished especially in the 1970s to 1980s-did not help shape the development of the new pastoral paradigm, a product of the larger problem that "pastoral studies are still regionally compartmentalized" (Behnke 2000, 142). Equating variability with uncertainty and mobility with flexibility has been one lasting result of this compartmentalization. The distinctions between these concepts are crucial to recognize in every pastoral setting, but in some areas-especially the non-montane environments where these words have become terms of art-the differences can be subtle and difficult to parse. However, in many non-arid mountain pastoral systems like the one presented in this paper, the important distinctions between variability and uncertainty and mobility and flexibility come into focus.

The new pastoral paradigm is not universally applicable. Nevertheless, it has been extremely influential to many scholars of pastoralism and has been erroneously globalized, especially by development practitioners. The FAO's 2016 Governance of Tenure Technical Guide 6, for example, which focusses on pastoral lands the world over, characterizes rangelands in general as uncertain and unpredictable, often using the terms uncertainty, variability, and heterogeneity interchangeably (Davies et al. 2016). The apparent over-diagnosis of environmental uncertainty and over-prescription of flexibility in institutions and grazing itineraries, then, has been a result of both a lack of consistency and precision in how these terms have been used as well as the dominance of a regionally-specific conceptual model-focussed on Sub-Saharan Africa and East Africa in particular-in global conversations about pastoralism.

In this paper, I critically review the ways that concepts of variability, uncertainty, mobility, and flexibility have been employed in literature on pastoralism. Building upon common threads found in the literature and using fieldwork from two pastoral groups in mountainous central Tajikistan, I will clarify the significant differences between these concepts and delineate more precise relationships between them. The definitions and explanations of the relationships that I advance in this paper are not novel, but they have not been clearly delineated at length in the context of the extant literature, as evidenced by the inconsistency and imprecision with which they are often invoked. Ensuring that the shared lexicon of pastoralism scholars in fact has shared meaning will improve our scholarship, especially when making cross-regional comparisons. In that spirit, one goal of this paper is to suggest a more precise vocabulary that can describe diverse pastoral contexts in comparable ways. In the process, I refer to inconsistencies and imprecisions in language in works that are, nevertheless, excellent and useful pieces of scholarship; my critiques are directed at how certain concepts are discussed rather than the central arguments of these works.

Most importantly, however, conflating these concepts or over extending the pastoral paradigm has significant practical implications for governance and pastoral development. It is challenging to develop institutions and access rules around uncertainty. Rather, institutions should be designed around the predictable patterns in resource availability and mobility needs that exist in a given context, leaving only enough institutional flexibility to address uncertainty that has been assessed empirically. An a priori embrace of unpredictability and flexibility can lead to advocacy for tenure arrangements that are inappropriate for their given context and unnecessarily hobbled by overly porous boundaries and unreliable land access.

As Jane Addison carefully acknowledged, "Institutional generation is not purely a product of biophysical conditions...nevertheless, ceteris paribus, biophysical characteristics do act as broad pressures or drivers that make some institutional arrangements more beneficial than others" (Addison 2016, 138). Certainly, socio-cultural and political factors may be primary determinants of land governance in many pastoral settings. This paper focusses on the relationship between environmental conditions and the demands of livestock mobility, however, as this dynamic is central to the way pastoral governance has been studied and explained by scholars and practitioners. 


\section{Analytical fallacies and key concepts in pastoralism studies \\ The first fallacy: Conflating terms \\ Variability and unpredictability/uncertainty}

All pastoralists must respond to environmental variability-differences over time and space in, for example, temperature, precipitation, or green forage abundanceand this variability can range from very predictable to very unpredictable. That is, environmental unpredictability or "uncertainty" is one sub-class of environmental variability; they are not interchangeable terms ${ }^{1}$. It is strikingly common, however, for the terms to be used in ways that either muddle their differences or even directly conflate their definitions.

Like everyone, pastoralists are faced with myriad uncertainties in their lives. Most literature on pastoralism, however, explains that there are specific types of uncertainty that are unique to this livelihood. Scholars and development practitioners routinely argue that pastoralists require special forms of resource governance because of the unique manifestations of variability and unpredictability found in pastoral contexts. The significant governance implications of these claims make it crucial to isolate the pastoralism-specific dimensions of variability and unpredictability to justify distinct property governance regimes.

While all sorts of people-pastoralists included-are subject to unpredictable variabilities in employment, markets, climate, politics, social life, crime, disease, and more (see Mehta et al. 1999; Meinzen-Dick and Pradhan 2002; edited volume by Scoones and Stirling 2020), the unique variability and uncertainty assigned to pastoralists concern primarily the spatiotemporal distribution of forage resources ${ }^{2}$. This is the subset of unpredictability that I focus on in this paper. Though in some temperate and Arctic rangeland systems temperature and snow cover can be additional factors constraining forage availability (Casimir and Rao 1992; Behnke 2000), precipitation almost always is used as a proxy for forage availability; in the vast majority of literature on pastoralism, environmental variability and unpredictability are about rain.

Environmental variability in pastoral systems is routinely referred to as "spatiotemporal variability", which conveys the importance of the interplay of spatial and temporal dimensions of variability for influencing

\footnotetext{
1"Variability refers to variation in environmental quantities... uncertainty refers to the degree of precision with which these quantities are estimated" (Van Belle 2008: 99).

${ }^{2}$ Some authors also discuss manifestations of variability and uncertainty in water sources (e.g. Peters 1987; McCarthy and Di Gregorio 2007; Bassett 2009). Water availability generally has less variation and far less spatial uncertainty than does forage availability, which is likely why it is not a primary focus of the literature.
}

pastoralists' strategies; after all, if variability were either purely spatial or purely temporal, there is no way that pastoral mobility would increase access to forage. Temporal variability alone is a central environmental dynamic for most settled agriculturalists-consider a crop calendar with cycles of planting and harvestingbut the spatial dimension is unique to pastoralists. Because resource abundance can fluctuate at a wide range of both spatial scales and temporal scales, the term "spatiotemporal variability" encompasses multiple disparate patterns.

Spatial environmental variation in pastoral systems includes, for example, differences between wetter and drier regions at farthest reaches of a given pastoral group's range-perhaps several hundred kilometres away from each other-but also microclimates in mountain areas that might be within a single kilometre. The chosen spatial scales-including both extent and resolution-of observation and analysis will sway any assessment of not only spatial variability and but also temporal variability (Augustine 2010; Brottem et al. 2014).

Environmental variability has been recognized at multiple time scales in pastoral contexts: interannual, seasonal, and intra-seasonal (this final scale is by far the least common, but see discussion of phenology in Hobbs et al. 2008). Some scholars specifically articulate these different types of variability (e.g. Davies et al. 2016; Hobbs et al. 2008) or at least define a single type of variability they are interested in (e.g. McCarthy and di Gregorio 2007), but more often variability is invoked vaguely and readers must infer which time-scale is described. Invocations of "unpredictability" or uncertainty (e.g. Ensminger and Rutten 1991; Niamir-Fuller and Turner 1999; Adriansen 2005) are often a sign that a scholar is referring to interannual variation. Significantly, the new pastoral paradigm was developed around high interannual variation in precipitation, and this particular type of temporal variation-as well as the conspicuously non-spatial calculation of the coefficient of interannual variation in precipitation at a single location-became the dominant measure of variability. The focus on interannual variability put uncertainty at the forefront of understandings of pastoral systems, especially with the publication of the edited volume Living with Uncertainty (ed. Scoones 1994), which focussed on African pastoral systems. As a stark visual representation of this, Davis's "Drylands Variability Map" shows only isopleths demarcating coefficients of interannual variation in precipitation greater than 33\% (Davis 2016, 17).

Though some contexts may be shaped predominantly by such unpredictable factors, many dimensions of environmental variability in pastoral systems can be predictable (Brottem et al. 2014): for example, temporal variability such as seasonal weather patterns, planting 
and harvest schedules, and some phenological cycles, or spatial variability such as differences between wetter regions and drier regions, floodplains, altitudinal zonation, or latitudinal differences, among others. In most pastoral systems, there will be a mix of some parameters of variability that are more predictable and others that are more unpredictable; the existence of some unpredictability does not preclude some predictability, and vice versa. Despite this, it is common for pastoralism literature, especially when concerning the arid tropics, to use the terms "unpredictability" and "variability" interchangeably, implicitly defining the latter as the former. This phenomenon is widespread: in influential and important articles both in the early years of the pastoral paradigm (e.g. Casimir and Rao 1992; Scoones 1992; Scoones 1994) and more recently (Davis 2016; Moritz et al. 2019); in surveys of the academic literature (NiamirFuller and Turner 1999; Vetter 2005) and in publications geared towards practitioners (Davies et al. 2016; IFAD 2020). In some cases, variability in pastoral contexts is explicitly defined as unpredictability. An IFAD guide for practitioners (Rota et al. 2018, 43) defines variability by explaining unpredictable and ephemeral rainfall, and an editorial introduction to a recent special issue of $\mathrm{No}$ madic Peoples defines variability as "unpredictable variations of vegetation structure, ground cover and precipitation" (Pappagallo and Semplici 2020, 181).

Many studies of pastoralism in mountains or temperate areas, in contrast, highlight the more predictable variability of seasons and altitude-determined spatial heterogeneity (e.g. Arbos 1923; Rhoades and Thompson 1975; Netting 1976; Balikchi 1990; Ehlers and Kreutzmann 2000; Fernández-Giménez 2002; Pérez León et al. 2020). Non-arid montane pastoral systems-including the one featured in this paper-very clearly illustrate that not all variability is unpredictable, but the mountain pastoralism literature has not directly engaged with the new rangeland paradigm thus far. Krätli and Schareika (2010) is one of the rare articles that explicitly identifies "unpredictable variability" as a distinct environmental phenomenon present in only a subset of the world's pastoral contexts, which altogether comprise "a large spectrum of realities" that they are not claiming to describe (606). While the distinction between more unpredictable and more predictable types of variability is often less obvious in arid and non-montane pastoral systems, it is nonetheless an important consideration in all pastoral contexts because of the implications for the strategies herders use to respond to variability, chiefly mobility, and flexibility.

\section{Mobility and flexibility}

Livestock mobility is the defining characteristic of pastoralism. It allows herders to cope with and even exploit environmental variability. However, mobility is only worthwhile as a response to certain types of variability. Absolute changes in, for example, precipitation or forage availability in a single area-purely temporal variabilityreveal nothing about mobility patterns. They can tell us whether the conditions are more or less suitable for livestock, but not how that might result in a livestock movement. This is because movements are in fact driven by the preference of one grazing area over another due to relative characteristics. Additionally, if one area is always preferred over others-if variability is purely spatialthen there would be no justification for mobility; the herd should just stay in that one preferred location. In short, mobility is a response to the variability over time between the relative suitability of multiple grazing areas. When this type of variability is regular and predictable, mobility patterns can be regular and predictable. However, when variability is more unpredictable, mobility must be flexible. Just as uncertainty is a sub-class of variability, flexible mobility is a sub-class of mobility.

Though flexibility and mobility should be understood as distinct concepts, the distinction between them is often unclear: "mobility and flexibility" frequently appears as a single phrase in the literature, and "mobility" is often used alone in order to signify flexible mobility (e.g. Ingold 1980; Galaty and Johnson 1990; Casimir and Rao 1992; Bassett 2009; Davies et al. 2016). Indeed, these two concepts are often difficult to separate in the subset of instances where livestock mobility is, in fact, flexible.

While the most general definition of livestock mobility is self-evident, there are no clear definitions that allow for ordering of pastoral groups as more or less mobile than one another (Turner 2011; Turner and Schlecht 2019). The two primary dimensions of mobility are frequency of movement and distance travelled (Galaty and Johnson 1990; Turner et al. 2016), but even these components do not lend themselves well to single metrics which could be assessed by looking at all daily herd movements or simply the movements between different sites of encampment (Butt 2016).

Mobility is not an end in and of itself (Turner 2011; Herrera et al. 2014; Davies et al. 2016), but a functional livelihood strategy. Moving around can play a role in helping herders avoid social and political unrest (Elam 1979; Fernández-Giménez 2002; Fernández-Giménez and Le Febre 2006) and access markets (Agrawal 1999; Starrs 2018), but of course, sedentary agriculturalists would also want to avoid unrest and seek access to markets. Mobility is uniquely important to pastoralists as a strategy to respond to the spatiotemporal heterogeneity-changes over time in the spatial distribution-of forage resources (Scoones 1994; Niamir-Fuller and Turner 1999; Fernández-Giménez 2002; McCarthy and di Gregorio 2007). In other words, pastoralists move with their herds to allow a herd to access the right 
"bundle" of land resources to sustain itself (Galaty and Johnson 1990).

Looking across pastoral systems at what exactly constitutes an adequate bundle, we can broadly characterize three potential objectives of mobility, which I term (1) "completing the set", (2) "hedging bets", and (3) "diffusing pressure". The first two objectives are most important to differentiate. Completing the set is the use of mobility to assemble a set of grazing areas in different ecological zones that are biophysically distinct in reliable and predictable ways-for example, wetter areas and drier areas, colder and warmer areas, or multiple locations along an altitudinal gradient-and grazed according to a repeating temporal pattern (e.g. as described by Ingold 1980; Fernández-Giménez and Le Febre 2006). The crucial need in agro-pastoral systems to keep animals away from cultivated crops or uncultivated fodder-growing areas during the growing season (e.g. Guillet 1983; Intigrinova 2010) can be considered a type of the completing the set objective, where mobility patterns based on predictable seasonal land cover cycles, though in this case the cycles are punctuated by the human activities of sowing and harvest.

When mobility is a strategy for hedging bets, the necessary bundle of land resources comprises a wide array of patches within a single ecological zone that may experience different forage abundances due to unpredictable climatic conditions (Galaty and Johnson 1990; Swallow and McCarthy 2000). These two objectives are not mutually exclusive; while in some pastoral contexts only one of these objectives might be present, they might both play important roles. For example, in the Malian "transhumance sheds" described by Brottem et al. (2014), herd movements between wetter regions and drier regions follow a regular seasonal pattern, while movements within the drier "northern dispersion zone" are less predictable and more driven by the unique conditions of that specific year. The third objective, diffusing pressure, is when livestock move in order to increase the total area grazed, thereby reducing the consumption of forage per areal unit, resting pastures so that they can recover, or both. As with the other objectives, diffusing grazing pressure can exist as a singularly prominent objective for livestock mobility or operate in concert with the others.

These three objectives of mobility are ideal types. Actual livestock movements are conditioned not only by the objectives of mobility, but also from diverse constraints on land access and travel. This typology is not intended to be used as a system for cleanly categorizing all pastoral groups, but as a tool to help discuss mobility needs and their implications for governance of pastoral land. Completing the set, hedging bets, and diffusing grazing pressure are all justifications for mobility, but they require and accommodate different types of property arrangements. To effectively hedge bets, herds must opportunistically respond to unpredictable environmental conditions through flexible mobility, but the two other objectives of mobility are based on predictable types of variability. In pastoral systems where hedging bets is not an important objective of pastoral mobility, flexible mobility is not needed.

The term "flexibility" is employed in diverse ways by scholars of pastoralism. Fernández-Giménez and Le Febre (2006) apply the term to strategies of livelihood diversification and destocking through sale or slaughter, and Swallow and McCarthy (2000), among many others, see adjustment in species composition of livestock holdings as an expression of pastoral flexibility. Nozières et al. enumerate 32 very specific types of pastoral flexibility, focussing especially on aspects of animal husbandry (Nozières et al. 2011).

While income diversification and inventory adjustments are strategies found in many non-pastoral contexts, in the pastoralism literature, flexibility most often refers to aspects of land use and access that are unique to this livelihood strategy. It is these types of flexibility that I focus on in this paper. First, flexibility can refer to the changeability of grazing itineraries themselves: the location of grazing areas (Neudert 2015; Moritz 2016) or the precise routes taken and timing of movements between predictable final destinations (Barth 1961; Brottem et al. 2014; Turner et al. 2016). Second, especially in recent literature on pastoralism, flexibility refers not to the mobility patterns themselves but to institutional structures and access rules that configure the array of options for livestock itineraries: the ability for spatial boundaries of territory and social boundaries of group membership (edited volume by Scoones 1994; Niamir-Fuller and Turner 1999; Marin 2006 in the Arctic; and many others) to be easily and repeatedly modified. Though flexible institutions and access rights may be present in a number of contexts, they are only essential for pastoral livelihoods when they are needed to facilitate flexibility in mobility. However, flexible mobility does not always require flexible institutions and access rights; if social and spatial boundaries are inclusive and large enough, then they can facilitate flexibility in mobility even when they are non-porous and stable.

Flexibility in land use and access has been described as integral to pastoralists' ability to cope with emergencies or extreme events (e.g. Fernández-Giménez 2002; Moritz et al. 2013) or more persistently erratic or unpredictable climates (e.g. Galaty and Johnson 1990; Casimir and Rao 1992; Scoones 1994). The relationship between size of resource management unit and unpredictable climates has also been noted (e.g. Tapper 1979; Swift 1994; McAllister et al. 2006; Davies et al. 2016).

\section{The second fallacy: Globalizing unpredictability and flexibility}

While mobility and variability are intrinsic to all the world's pastoral systems, we have seen above that not all 
Table 1 Illustrative excerpts from practitioner publications regarding uncertainty and flexibility

\begin{tabular}{|c|c|}
\hline Publication [organization] & Comments on uncertainty \\
\hline $\begin{array}{l}\text { Herrera et al. (2014). Governance } \\
\text { of Rangelands } \\
\text { [N/A] }\end{array}$ & $\begin{array}{l}\text { "Unpredictable and comparatively unproductive lands... } \\
\text { rangelands are so vast and unpredictable that commun } \\
\text { management has been the key to survival" (xviii). }\end{array}$ \\
\hline $\begin{array}{l}\text { Davies et al. (2016). Improving } \\
\text { the Governance of Pastoral Lands } \\
\text { [FAO] }\end{array}$ & $\begin{array}{l}\text { "Pastoralism is, to a large extent, an adaptation to } \\
\text { ecological and climate variability [and] other sources of } \\
\text { unpredictability" (11). } \\
\text { "[Pastoral lands] are challenging and unpredictable } \\
\text { environments" (12). } \\
\text { One of the "defining characteristics of pastoral } \\
\text { management and governance" is "Variable and } \\
\text { unpredictable climate" (24). }\end{array}$ \\
\hline
\end{tabular}

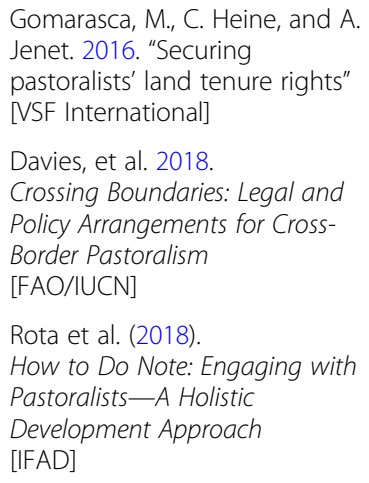

When defining pastoralism: "Pastoralism...takes advantage of the characteristic instability of rangeland environments, where key resources... become available in short-lived and largely unpredictable concentrations" (42).

\section{Comments on flexibility}

"The success of pastoralism relies on flexibility" (25)

al

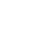

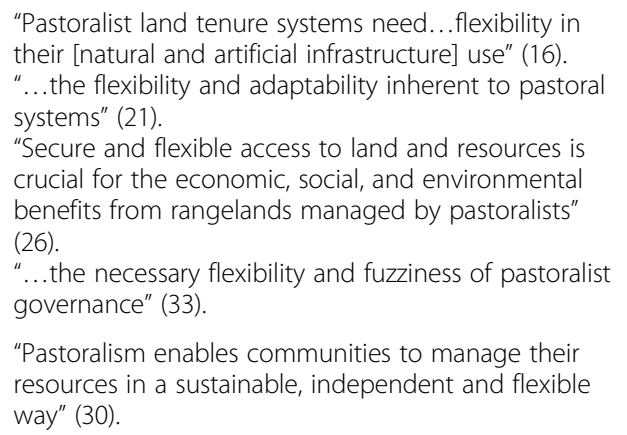

"Pastoralist land tenure systems need... flexibility in their [natural and artificial infrastructure] use" (16). "...the flexibility and adaptability inherent to pastoral systems" (21).

"Secure and flexible access to land and resources is crucial for the economic, social, and environmental benefits from rangelands managed by pastoralists" (26).

"...the necessary flexibility and fuzziness of pastoralist governance" (33).

"Pastoralism enables communities to manage their resources in a sustainable, independent and flexible way" (30).

"Mobility... is essential for... managing the unpredictable climate" (1).
"... inherent flexibility of arrangements for natural
resource management [in pastoral contexts]" (xiv).

"Crucial aspects of pastoralist specialization are...the development of flexible resource management systems" (42). pastoral contexts are characterized by high levels environmental uncertainty and do not, therefore, necessitate flexible livestock mobility patterns. When these pairs of concepts-variability and unpredictability, on the one hand, and mobility and flexibility, on the other-are erroneously conflated, however, it is impossible to invoke them selectively and deliberately. The result is the second analytical fallacy that pervades much of the literature on pastoralism: the over-diagnosis of uncertainty as intrinsic to pastoral systems and over-prescription of flexible mobility as a requisite response to this uncertainty. This fallacy manifests itself as (1) overly specific global-scale characterizations of pastoralism as a livelihood strategy and (2) local-scale mischaracterizations of specific pastoral contexts as unpredictable.

Given the diversity of pastoral systems across the globe, it is extremely difficult to accurately say much that all these systems have in common. Nevertheless, non-academic praxis-oriented organizations have released publications that do just that, with the noble goal of elevating the needs and priorities of pastoralists world-wide. These publications almost certainly produce far more good than harm, but in their endeavour to create a cohesive "bloc" of pastoral peoples, they often define pastoral systems too narrowly by claiming that environmental unpredictability and flexible mobility are intrinsic aspects of pastoralism as a livelihood (see Table 1). A recent online discussion about the definition of pastoralist similarly led to statements about "the inner [sic] uncertainty of rangelands" and how "pastoralism is about creating livelihoods in highly variable environments", presumably referencing unpredictability given the extreme seasonal variability in many non-pastoral agricultural areas (Pastoralist Knowledge Hub 2020). Though less common, there are also examples of over-extension in academic literature of conditions of uncertainty (Nori 2019) and necessity of flexibility (Fernández-Giménez 2002; Butt 2016) to all pastoral contexts.

When pastoralism in general is defined with concepts that fit only a subset of examples, these concepts condition observers' assumptions. Moritz et al. (2013, 363364) argue that scholars' fervent and necessary rebuttals of the tragedy of the commons have led to "such a commitment to the pastoral commons that we see it even when pastoralists tell us it" is not there. Similarly, the vital interventions that explained and defended the importance of flexible mobility in certain especially unpredictable pastoral contexts has led people to see uncertainty and the need for flexibility when they are not there, including in cases like the one described in this paper. There are academic examples of this in 


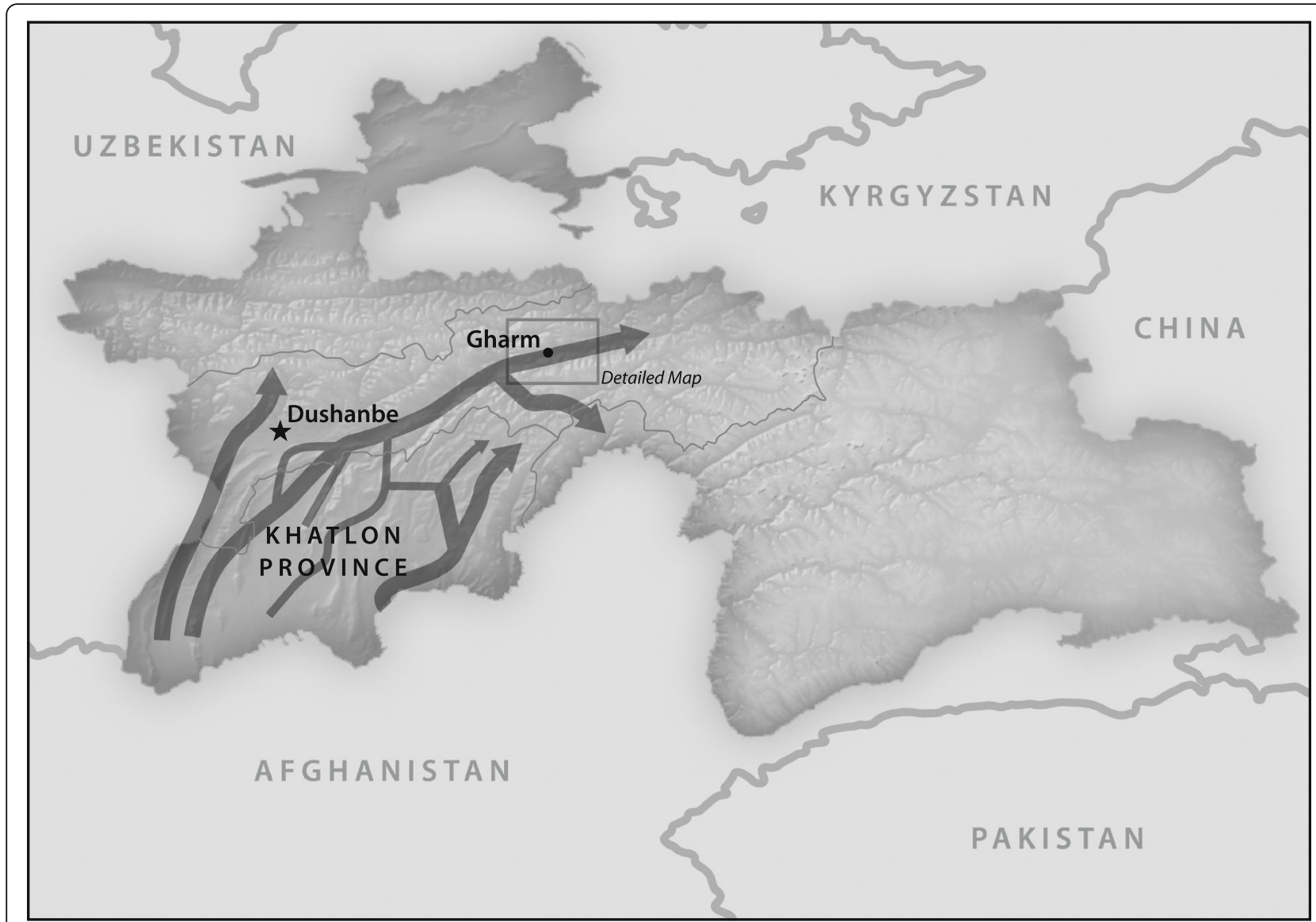

Fig. 1 Map of Tajikistan. Arrows show general patterns of long-distance transhumance routes to summer pastures, including those used by nonlocal herders in the study area

studies of Russia (Intigrinova 2010) and Central Asia (Steimann 2012 ${ }^{3}$ ). In a 2011 conference presentation about pasture tenure policy in Tajikistan, an international expert's recommendations stressed the need to facilitate flexibility in grazing patterns. And in a 2018 online discussion where I pointed out that uncertainty was not a uniformly dominant aspect of all pastoral systems, a prominent voice in pastoralism advocacy challenged my point, arguing that because of "unpredictable climatic events every so often such as bad winter snows...flexibility would be required" even in the temperate Central Asian climates I was writing about.

\section{Study area}

I conducted research in Rasht district of central Tajikistan, a post-Soviet country in Central Asia (Fig. 1). This mountainous district is bisected by the Surkhob River. Fieldwork was conducted primarily in Askalon

\footnotetext{
${ }^{3}$ Steimann does, however, offer a very nuanced and well-considered view of uncertainty.
}

sub-district (jamoat), bounded in the north by the Surkhob River and in the south by the ridges of the Peter the First (Pyotri Yak) mountain range to cover a total of $94 \mathrm{~km}^{2}$ (Fig. 2). The sub-district's elevation ranges from 1340 masl on the banks of the river up to 3900 masl at the highest peaks that define its southern border. Climate data is only available for the lower elevations in this area, where temperatures average $-3.5^{\circ} \mathrm{C}$ in January, the coldest month, and $24{ }^{\circ} \mathrm{C}$ in July and August, the warmest months (all climate values calculated by author from monthly data in Williams and Konovalov (2008)). An average of $743 \mathrm{~mm}$ of precipitation falls a year, with a coefficient of interannual variation of 0.23 . Half of the year's rain falls from March through May, and the seasonality index for precipitation (after Walsh and Lawler 1981) is 0.55 .

Askalon is home to 4200 residents spread across 13 villages, the highest of which is 2200 masl. Roughly $80 \%$ of the households here raise livestock, and raising livestock is the primary source of income for about onequarter of the households in the sub-district. 
Households here keep a mixture of sheep, goats, and cattle. While all three species are useful for household meat consumption or live sales for cash, only cattle are milked, and households here do not use or sell their animals' skin or wool. Though there are several households with large herds of over 100 small-stock, the average household owns two to four head of cattle and eight to 10 head of small-stock. These families' animals are stallfed indoors for the coldest months of the year, then graze in collective herds in spring-fall pastures near the village and summer pastures at higher altitudes.

In the summer, the livestock population in this area balloons, as around 20,000 head of sheep and goats arrive as part of a long-distance seasonal migration from the hotter and drier lowlands in Khatlon province of southwestern Tajikistan. Each of these herds has roughly 2000 head of sheep and goats and is managed by teams of three to five professional herders. While the locals who live full-time in Askalon are ethnic Tajiks, these herders are either Qallugh or Loqay, two Turkic ethnic groups most prevalent in southwestern Tajikistan. These non-local herds are mostly managed as part of giant agricultural enterprises that send dozens of herds to different parts of the country, and are carefully managed, with their own winter grazing areas, fodder supplies, large shelters, and dedicated veterinarians and breeding specialists at their home bases in Khatlon province.

\section{Methods}

This study is based on a review of literature on pastoralism and qualitative field research conducted in Tajikistan in 2016 and 2017 as part of a broader project examining the evolution of pastoral practices and pastoral land tenure regimes in the context of post-Soviet economic and legal reforms. The field work in Tajikistan was conducted in 2016 and 2017. In Dushanbe, the national capital, the author interviewed government employees, academic researchers, and NGO employees. Most of the field work, however, occurred in the rural Rasht Valley, where the author conducted 11 months of field work in Rasht and Lakhsh districts, focussing especially on the Askalon and Hijborak sub-districts (jamoats).

Though cross-checked with information gleaned from the broader research activities, including months of observation while living in the rural study area, this paper predominantly draws on nine focus group discussions (FGDs) with livestock owners residing in southern Rasht district, 12 interviews with professional transhumant herders from Khatlon province who spend their summers in high altitude pastures in Rasht, and four key informant interviews with locals who are owners of large herds, owners of large summer pastures, and/or professional herders.

Each FGD had three to four participants-for a total of 29 participants-who were selected with the help of local intermediaries as representing average livestockowning citizens who were neither elite nor especially impoverished. These FGDs were semi-structured conversations based on the same interview script which asked about decision-making related to livestock management over the course of the year, access to pastures and fodder-growing land, and relationships with nonlocal herders. Conversations lasted 40-90 min. The 12 professional transhumant-herder interviews captured $100 \%$ of the non-local herds that were present in Askalon and Hijborak sub-districts in 2016. These interviews were conducted at these herders' summer camps.

A survey was administered to 108 households of Askalon sub-district (a 19.3\% sample) in 2016, which asked about the relative importance of different livelihood activities, livestock sales and purchase over time, land ownership, summer grazing locations, and grazing fees. The survey was stratified by village, wealth, livestock holdings, and female- versus male-headed household. It provided a general picture of the economic importance of livestock in the areas and the prevalence of different management strategies, while the focus groups illuminated the rationales for these strategies.

\section{Results}

Pastures in Askalon and Hijborak sub-districts are grazed by herds of locally owned livestock that spend their entire years in the area as well as non-local herds that travel for 15-30 days from Khatlon province with professional herders to graze mountain pastures in the summer. Within each of these groups there are different management choices available; the presence of any choice, by definition, means that there is some element of flexibility in how livestock are managed. Both groups' experiences illustrate the necessity of livestock mobility; however, none of the herders in the study area appeared to use flexible mobility to opportunistically track spatiotemporally unpredictable forage resources. While grazing areas and movements are extremely predictable, pastoral flexibility manifests in two ways (1) flexible timing for livestock movements between pre-determined grazing areas that are consistent from year to year and (2) decisions made each year by livestock owners about where to send their animals in the summer based predominantly on household wealth, labour availability, and which professional herder would be caring for their animals in a given area. Pastoral land governance in the area is structured by these highly 


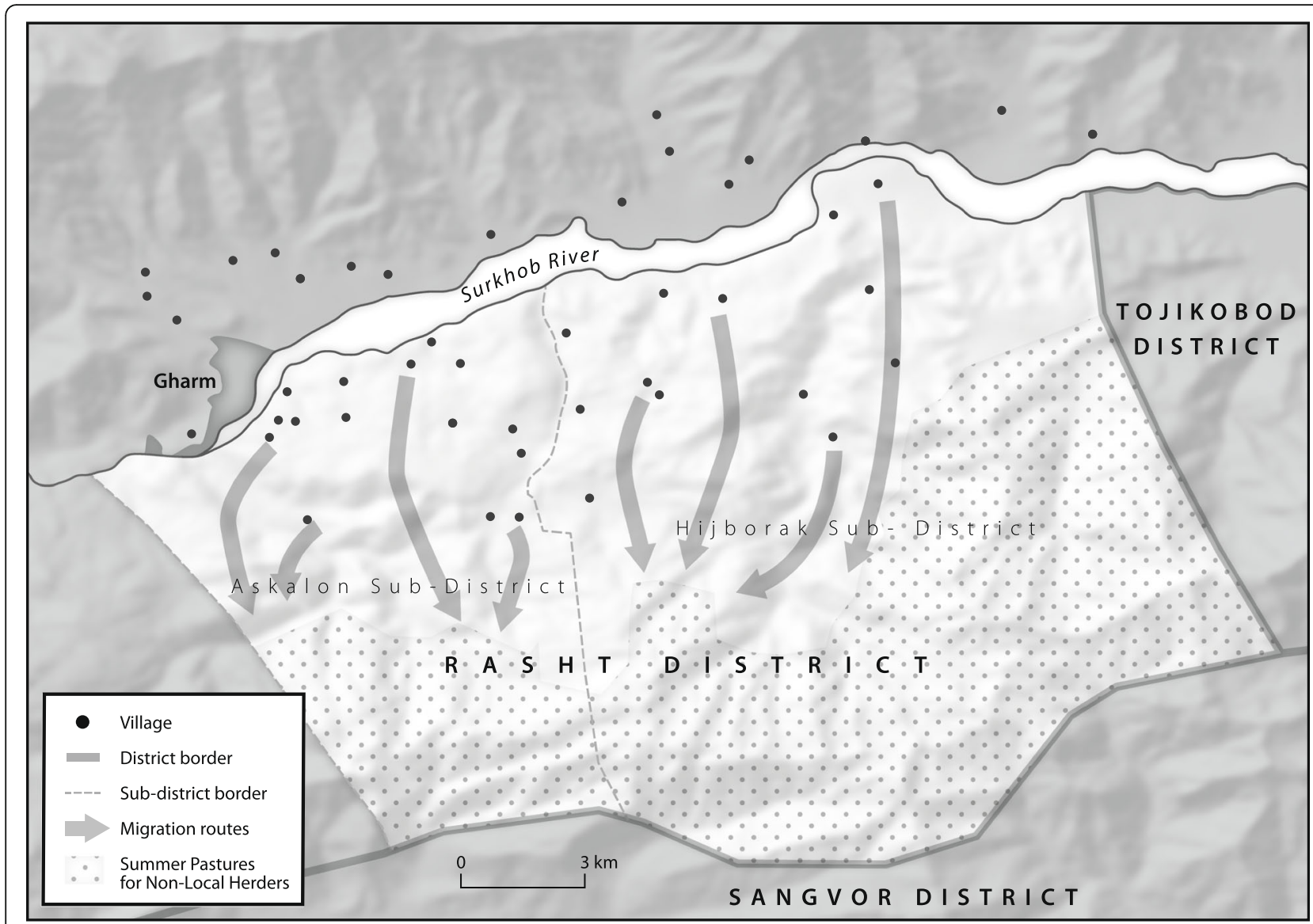

Fig. 2 Map of Askalon and Hijborak Sub-Districts in southern Rasht District. Arrows show general patterns of short-distance transhumance routes used by local herders in the study area. Dotted area is grazed solely by non-local herders

predictable dynamics, yet can accommodate these minor manifestations of flexible management.

\section{Mobility and flexibility for local livestock}

The general seasonal pattern for livestock based in Askalon and Hijborak sub-districts is static. Livestock overwinter in their owners' private animal barns, where they are stall-fed for roughly 6 months. In the spring, each village or neighbourhood's animals are aggregated every morning into collective herds-one for cattle and one for sheep and goats-returning back to their owners' homes in the evening after grazing on pasture or land that will be protected in the summer as fodder-growing land. Herding responsibility during this time rotates daily through the livestock-owning households. After several weeks of spring grazing, these village herds then fracture, as the families in Askalon can choose to pay to send their animals off with one of several teams of professional herders or keep their animals at home and grazing with the village herd all summer. Summer pastures (ayloqs) are generally more remote and higheraltitude. In the fall, all livestock return to the village to graze on both the spring pastures and post-harvest crop residues until they go back into their barns when the snow falls.

Herd mobility is an essential part of this system, driven by both completing the set and diffusing pressure motivations. At the seasonal timescale, livestock move consecutively between biophysically distinct zones across an altitudinal gradient to access pastures that are snow-free and dense with forage. At daily and weekly timescales, livestock mobility reduces grazing pressure on any one given area. Perhaps just as important as its role in providing access to forage resources as they become available, livestock mobility also is vital for ensuring that certain fodder-growing areas around the village remain ungrazed long enough in the summer to provide sufficient fodder harvests to sustain animals indoors when they are stall-fed during the winter.

This mobility is extremely predictable, insofar as it is responding to the certain changes of the seasons and taking advantage of fixed altitudinal gradients (see Fig. 3). Each village has well-defined spring and fall grazing areas, and these are small enough that the entire available area is grazed every 


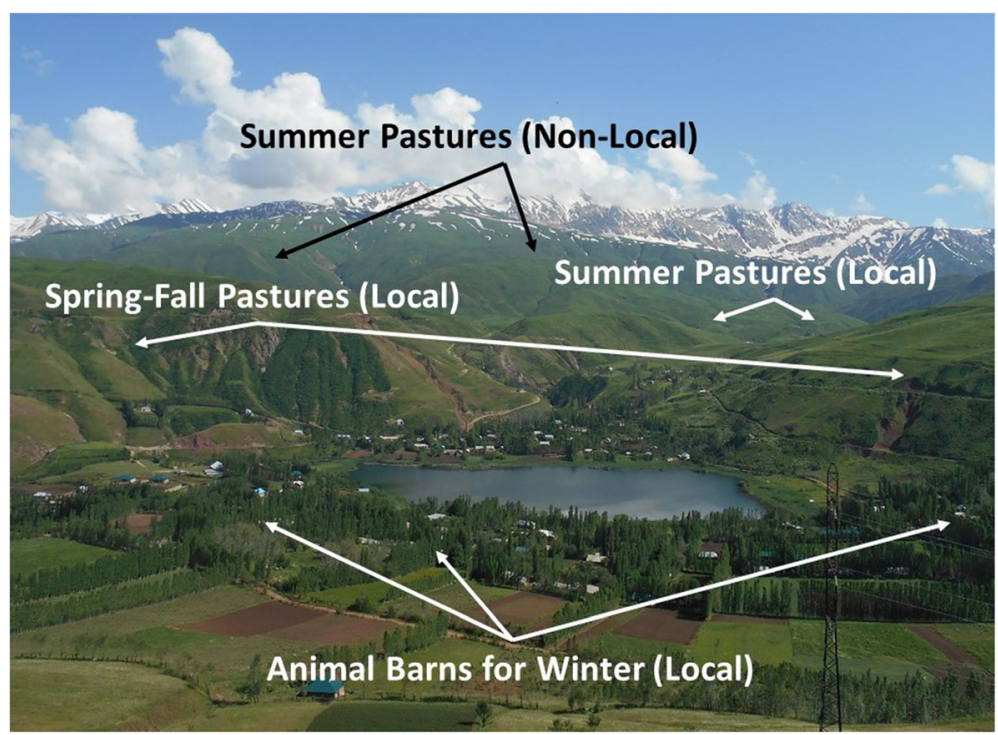

Fig. 3 Spatial organization of livestock areas in typical village of study area

year. The areas grazed in the summer are also identical every year, regardless of environmental conditions. The territories of all of these areas are delineated by formal legal boundaries. These boundaries are widely recognized and respected, so monitoring and enforcement of boundaries seldom involves the government but can if disputes escalate.

While grazing locations for each season are fixed, the timing of seasonal transitions is flexible. Sheep and goats generally leave the animal barns to begin spring grazing as soon as the snow melts, when they begin feeding on grass from the previous year that had been under the snow. Cattle begin grazing around a week later, mostly feeding off early growth of new grass. From year to year, the start date for spring grazing can reportedly vary by as much as a month, usually starting around mid- to late April. By mid- to late May, grazing is prohibited on areas that will grow winter fodder, but timing of arrival at summer pastures is also flexible, determined by when the higher altitude summer pastures are snow-free. Snowfall also dictates when herds return to the lower-

Table 2 Summer grazing options for local herders in Rasht Valley

\begin{tabular}{|c|c|}
\hline Summer grazing options & Advantages \\
\hline $\begin{array}{l}\text { Option 1: Keep in village pasture } \\
\text { Part of an aggregated village herd } \\
\text { and herded by members of } \\
\text { livestock-owning households on a } \\
\text { rotating basis }\end{array}$ & $\begin{array}{l}\text { - Cheaper (no need to pay for } \\
\text { herding labour) } \\
\text { - Able to obtain milk (cattle only) } \\
\text { - Reduced risk of livestock theft, } \\
\text { loss, or injury }\end{array}$ \\
\hline $\begin{array}{l}\text { Option 2: Send to remote } \\
\text { pasture } \\
\text { Herded by professional herders as } \\
\text { part of a larger herd }\end{array}$ & $\begin{array}{l}\text { - Livestock gain more weight } \\
\text { (higher-quality, more abundant } \\
\text { forage) } \\
\text { - No need to allocate household } \\
\text { labour to herding }\end{array}$ \\
\hline
\end{tabular}

elevation fall pastures, and ultimately when they move from fall pastures back into the animal barns for stallfeeding. Because herds begin stall-feeding as soon as pastures are covered with snow, extreme snowfall events occur after animals have already stopped leaving their barns for fall pastures ${ }^{4}$. This contrasts with contexts elsewhere in Central and Inner Asia where extreme cold weather events-sometimes known as $d z u d s$ or dzhutscan be significant unpredictable drivers of herd movements (Robinson and Milner-Gulland 2003; Kerven 2004; Fernández-Giménez et al. 2015).

Though a household's livestock will almost certainly spend every summer in an area within $10 \mathrm{~km}$ of its home village, they may graze in a different area each summer. For example, $24 \%$ of survey respondents who had livestock in the summers of 2015 and $2016(n=75)$ sent them to different locations each of those 2 years. Every year, the same grazing territories-ranging in size from 50 to 250 ha-will be grazed by professional herders, but livestock owners can choose which of these to send their animals to. While this decision can be considered an example of flexible livestock management, it is not an example of flexibility in response to unpredictable environmental conditions. In fact, forage quality is just one of the many factors that are weighed when making this decision, and not necessarily an important one.

The first choice a livestock owner makes is whether to keep their animals ${ }^{5}$ in the village-managed herd that

\footnotetext{
${ }^{4}$ Presumably, it would be possible for an extreme snow event to also be the first snow of the year, marking the end of grazing of fall pastures.

${ }^{5}$ This is not a decision that has to be made for milking cattle; because there is no milking at remote summer pastures, every household will keep these animals at home over the summer.
} 
grazes in the areas adjacent to their village. Because livestock-owning families take turns grazing these herds rather than paying professional herders, this option is cheaper than sending animals away but places additional demands on household labour. Families that keep their livestock around the village are usually poorer and have sufficient herding labour to contribute. Some heads of household have elected to keep their animals at home because of negative experiences with their animals getting lost, injured, killed, or stolen when out of their care for several months. The cost savings, however, is the primary reason to keep livestock in the village herd.

In general, livestock owners with the means to do so will prefer to send their animals away from the village to more remote summer pasture areas because there is more forage and their livestock will gain more weight. In some cases, this is a livestock owner's only option either because they are not able to provide the household labour to take their turn grazing the village herd or because they live in a village where there is not adequate pasture to support an aggregated village herd over the summer (Table 2).

Livestock owners who have decided to send their livestock with a professional herder must next choose which herder to send them with. Professional herders will graze livestock on land that they either own themselves or have secured access to with contracts with the land's owner; long before summer, it is clear which area each professional herder will take his herd to. For livestock owners, then, the decision of who to send their animals with and where to send their animals is one and the same. When making this decision, livestock owners report that they consider both the quality of the pasture and the quality of the herder. The characteristics of a good pasture, as described by livestock owners who do not necessarily visit these pastures themselves, are general and obvious: a large land area (100 hectares or more), ample water, and lots of good quality grass. A good herder is described as one who has a lot of experience, has a track record of not losing animals, changes camps frequently, gives salt and waters animals at the right time, and has a lot of livestock owners wanting to send their animals to him. Oftentimes, however, the decision of who to send your animals with to comes down to logistics. Some livestock owners prefer to send their animals with a herder who goes up to the summer pastures earlier in order to alleviate winter fodder shortages. Some herders accept in-kind payments of, for example, one out of every 10 or 15 sheep or goats that they herd for a summer, which appeals to cash-poor livestock owners. Lastly, though most interviewees claimed it did not influence their decision-making, many livestock owners sent their animals with summer herders with whom they had some sort of familial or neighbourhood connection.

The Soviet past has influenced aspects of this system, but the ways that land is used by livestock owners is based on the needs of the animals and diverges from the situation in the Soviet era and even the land policies advanced by the current government. During the Soviet era, household livestock holdings were limited to one head of cattle and five heads of sheep or goats. Household and state-owned herds had spatially distinct grazing areas. These state-owned herds are no longer present, and private livestock ownership has increased rapidly. During the Soviet era, the long-distance migrations between Khatlon province and Rasht were bi-directional, with many Rasht-based herds migrating to Khatlon during the winter. The system of privately owned summer pastures where herds are watched by professional herders for a fee is an innovation. But the story is not simply one of increased private land management. In the post-independence period, waves of land reforms led to the privatization and individualization of pastures, often against the will of those who received fragments of pasture. In many villages, the "village pasture" comprises many dozens of separate pasture plots that are individually owned, but the borders between these are ignored in practice and the agglomeration of pastureland is grazed in common as a single land unit.

\section{Mobility and flexibility for non-local livestock}

The importance of livestock mobility is even more pronounced for those sheep and goat herds travelling up to $400 \mathrm{~km}$ to the Rasht Valley's mountain pastures from their winter pastures in the lowlands of Khatlon province in southwestern Tajikistan. These long migrations enable herds to complete the set of predictably distinct ecological zones necessary to support animals yearround. The lush mountain pastures dependably provide abundant forage and water during the summer, when the herds' winter areas in the lowlands are invariably drier and more barren, unable to fatten the sheep and goats nearly as well as the mountain pastures. By returning to the lowlands for the rest of the year, however, the herds avoid the harsh mountain winters that require local livestock to spend all winter indoors and supplied with large fodder stores. Seasonal livestock migrations between Khatlon and Rasht have occurred for decades, if not centuries, ceasing with the onset of Tajikistan's civil war in 1992 and resuming gradually in the mid- to late2000s. According to both the non-local shepherdsmany of whom come from families that have been leading these seasonal livestock drive generations-and locals who live in villages adjacent to the summer pastures, the very same areas have been grazed for decades. 
Before starting their multi-week trek to the summer mountain pastures of Rasht district, herders coming from Khatlon district already know which areas have been assigned to them for summer grazing, usually around 300-400 ha. These herders are employees of agricultural firms with managers who oversee the legal aspects of securing use rights for summer grazing areas and also assign teams of herders to herds of sheep and goats and to specific locations. Selecting the summer grazing area, then, is the responsibility of the herders' bosses rather than the herders themselves. At the scale of the agricultural firm, summer grazing areas are quite static. With some minor variation, a given firm will send their herds to the same set of summer grazing areas each year. Herders report that managers like to send the same herds to the same places year after year because the livestock become accustomed to particular areas. While a given herd of livestock returns to the same set of pastures year after year, herding teams - the humans-may be assigned to different herds and locations different years.

Non-local livestock graze on summer pasture that lies within State Reserve Land ${ }^{6}$ (Zamini Zakhirai Davlati). Use rights for this class of federal land are obtained through short-term contracts-usually 1-year contracts in Rasht district-from the district offices of the State Land Committee. All contracts are issued before the spring migration to the summer pastures begins and pasture conditions can be observed. A herding team and its animals will stay within their allotted area no matter what environmental conditions they face upon arrival. The predictable spatiotemporal environmental variability across seasons and altitudes has enabled these secure and dependable institutional arrangements to form.

For herds moving from Khatlon to Rasht, the seasonal migration occurs along official livestock transit routes (rohhoi chorvoguzar) that are state-sanctioned and under the purview of Ministry of Agriculture's Pasture Trust (Tresti Charogoh). These routes are mostly unchanged since the Soviet era, but some herders report taking minor detours to avoid stretches recently constricted by encroaching cultivation. These detours are exceptions, though, and the well-established network of transit routes means that flexibility during the seasonal migrations is only manifested in the timing of movements. The lead herder (referred to as starchiy) for each herd makes his own personal decision about when to begin spring and fall migrations. Those who leave early in the spring face harsher weather along the way and may find that much of their summer pasture is still snowbound.

${ }^{6}$ In the study area, only State Reserve Land was used by herds from Khatlon. However, in some nearby areas, these herds would also use State Forest Land.
Those who leave later in the spring have a harder time filling their animals up during their month of travel, as the slivers of pasture on the margins of the transit routes have already been grazed by many other herds. Those who leave at peak time must contend with high traffic from other herds following the same routes. The same trade-offs must be considered for the return trip, but herders must additionally make sure that they time their return around the mating period, which can happen in mountain pastures before the fall migration, but most often occurs after herds return to the lowlands around the end of September.

Within their summer pastures in Rasht district, nonlocal herds use mobility both to complete the set at a smaller scale and also to diffuse grazing pressure. Each mountain pasture territory delineated for a single herd is oriented to contain its own altitudinal gradient. In this study area, a single non-local herd's summer grazing territory would vary 500-700 $\mathrm{m}$ in elevation, with the highest altitude territory stretching from 2700 to 3300 masl. Over the course of the May-September grazing period, non-local herders take advantage of this small-scale altitudinal gradient, first setting up camps in lower altitude areas-used as hubs for daily grazing orbits-moving to the higher reaches as weather warms, and moving back down to the lower areas within their grazing territory for the month before they begin their fall migration. Each herd rotates between four to seven different camps $\left(q^{\prime} \tan ^{7}\right)$ over the course of their time in Rasht, using some camps multiple times. Herders expect to rotate roughly every 15 days, but their precise timing of migration depends on a visual appraisal of the condition of the land around them. Each movement from one camp to another is not necessarily an explicit move from one altitude to another. For example, one lead herder considered their team to have three low altitude camping locations and three high altitude camping locations but did not think of them as on a gradient beyond those two categories.

Here again, we see that even within just the summer grazing period, livestock mobility is an integral part of herd management. Because summer grazing territories are circumscribed, pre-determined, and grazed in their entirety, there is no manifestation of flexibility in the location or spatial extent of grazing. This maintenance of distinct grazing territories is particularly notable because almost all the non-local herds in the study area belong to the same company, so use rights for all these pastures are held by a single entity. The boundaries of grazing areas for

${ }^{7} Q^{\prime} \tan ($ Қътан) comes from Uzbek qo'ton (қӯтон) and specifically refers to an overnight resting point for sheep and goat herds rather than a camp for humans, though the herders will also camp in the same location (Mahmudov et al. 2012). 
these herds are an internal organizational strategy rather than a practice of exclusion by powerful actors, so the adherence to these boundaries can be seen as evidence that they were not discernably at odds with the needs of the livestock. There is some flexibility in the exact timing of grazing movements, but the sequencing of movements is based on predictable seasonal temperature patterns and stable altitudinal differences (Table 3).

\section{Discussion}

The dynamics of this case study illustrate the differences between variability, uncertainty, mobility, and flexibility more clearly than do many other pastoral contexts. While central Tajikistan is not representative of all pastoral contexts, these distinctions are relevant in every system. The distinctions do concern definitions of terms, but these definitions are crucial to understanding mobility and also have very real practical implications. Advocates and scholars of pastoralism consistently invoke these terms when justifying land tenure and resource governance imperatives, so the way we use these terms will almost always have consequences for livelihoods, economies, politics, and conflict.
Several guiding principles emerge from this refinement of definitions.

\section{Principles for understanding pastoral systems All pastoral contexts require mobility}

Mobility is not simply a strategy to cope with uncertainty, but a strategy to accommodate and take advantage of all types of spatiotemporal variability in forage availability. Even where environmental patterns are more predictable-as in the central Tajikistan case described here-it is still imperative that pastoralists can maintain livestock mobility to respond to predictable variability. Those working in these types of pastoral settings must still be vigilant about the dangers posed to mobility, including pasture fragmentation and dissolution or constriction of livestock transit corridors.

\section{Some, but not all pastoral contexts are characterized by unpredictability}

It is admittedly difficult to categorize a pastoral system as "predictable" or "unpredictable". Certainly, there is no single measure for unpredictability for pastoralists, and even if there

Table 3 Livestock mobility patterns in study area (April through November)

\begin{tabular}{|c|c|c|c|c|c|c|}
\hline \multirow[t]{2}{*}{ Group } & \multicolumn{2}{|l|}{ Environmental context } & \multicolumn{3}{|c|}{ Mobility response } & \multirow[t]{2}{*}{ Institutional arrangements } \\
\hline & Type of variability & Predictability & Season & Description & Justification type & \\
\hline \multirow[t]{4}{*}{$\begin{array}{l}\text { Local } \\
\text { herds }\end{array}$} & $\begin{array}{l}\text { Seasonal and altitudinal } \\
\text { variation in temperature } \\
\text { (including snowfall and } \\
\text { snow melt) }\end{array}$ & $\begin{array}{l}\text { Predictable; some } \\
\text { temporal fluctuations } \\
\pm 2 \text { weeks }\end{array}$ & Spring ${ }^{a}$ & $\begin{array}{l}\text { Begin grazing of spring- } \\
\text { fall pastures }\end{array}$ & $\begin{array}{l}\text { Completing the } \\
\text { set }\end{array}$ & $\begin{array}{l}\text { Clearly defined territorial } \\
\text { boundaries and user group. } \\
\text { Grazing allowed until village } \\
\text { leaders reserve land for fodder } \\
\text { growth. }\end{array}$ \\
\hline & & & Summer $^{a}$ & $\begin{array}{l}\text { Move up to summer } \\
\text { pastures }\end{array}$ & $\begin{array}{l}\text { Completing the } \\
\text { set }\end{array}$ & $\begin{array}{l}\text { Clearly defined territorial } \\
\text { boundaries and user group. }\end{array}$ \\
\hline & & & & $\begin{array}{l}\text { Rotating camps within } \\
\text { summer pastures }\end{array}$ & $\begin{array}{l}\text { Completing the } \\
\text { set and diffusing } \\
\text { pressure }\end{array}$ & $\begin{array}{l}\text { Access through deed or } \\
\text { temporary contract with deed- } \\
\text { holder. }\end{array}$ \\
\hline & & & Fall $^{a}$ & $\begin{array}{l}\text { Return down to village } \\
\text { to graze on spring-fall } \\
\text { pastures }\end{array}$ & $\begin{array}{l}\text { Completing the } \\
\text { set }\end{array}$ & $\begin{array}{l}\text { Clearly defined territorial } \\
\text { boundaries and user group. } \\
\text { Grazing allowed after fodder } \\
\text { harvest. }\end{array}$ \\
\hline \multirow[t]{3}{*}{$\begin{array}{l}\text { Non- } \\
\text { local } \\
\text { herds }\end{array}$} & $\begin{array}{l}\text { Seasonal and altitudinal } \\
\text { variation in temperature } \\
\text { (including snowfall and } \\
\text { snow melt) }\end{array}$ & $\begin{array}{l}\text { Predictable; some } \\
\text { temporal fluctuations } \\
\pm 3 \text { weeks }\end{array}$ & $\begin{array}{l}\text { Mid- } \\
\text { spring }\end{array}$ & $\begin{array}{l}\text { Migrate from lowlands } \\
\text { to summer mountain } \\
\text { pastures }\end{array}$ & $\begin{array}{l}\text { Completing the } \\
\text { set }\end{array}$ & $\begin{array}{l}\text { Clearly defined state-owned } \\
\text { livestock migration routes open } \\
\text { to all herds. }\end{array}$ \\
\hline & $\begin{array}{l}\text { Intra-seasonal and } \\
\text { altitudinal variation in } \\
\text { temperature; grazing- } \\
\text { induced variability in } \\
\text { forage density }\end{array}$ & & Summer $^{\mathrm{a}}$ & $\begin{array}{l}\text { Rotating camps within } \\
\text { summer pastures }\end{array}$ & $\begin{array}{l}\text { Completing the } \\
\text { set and diffusing } \\
\text { pressure }\end{array}$ & $\begin{array}{l}\text { Clearly defined territorial } \\
\text { boundary and user group. } \\
\text { Access through single-year } \\
\text { contracts with State Land } \\
\text { Committee. }\end{array}$ \\
\hline & $\begin{array}{l}\text { Seasonal and altitudinal } \\
\text { variation in temperature } \\
\text { (including snowfall and } \\
\text { snow melt) }\end{array}$ & & Early fall & $\begin{array}{l}\text { Return from summer } \\
\text { mountain pastures to } \\
\text { lowlands }\end{array}$ & $\begin{array}{l}\text { Completing the } \\
\text { set }\end{array}$ & $\begin{array}{l}\text { Clearly defined state-owned } \\
\text { livestock migration routes open } \\
\text { to all herds. } \\
\text { Lowland pastures have clearly } \\
\text { defined territorial boundaries } \\
\text { and user groups. Access through } \\
\text { deed. }\end{array}$ \\
\hline
\end{tabular}

aThese mobility patterns are combined with daily grazing orbits. Daily grazing is a "diffusing pressure" response to grazing-induced variability in forage density which is predictable because it is caused by the herds themselves 
was one, we would then have to determine a threshold for this hypothetical measure. A system may display more predictability at larger scales and less at smaller scales (Illius and O'Connor 1999; Sullivan and Rohde 2002; Brottem et al. 2014), so scale of analysis would affect any assessment even with an established measure and threshold.

Despite the absence of a precise assessment tool, we can realize that in many pastoral contexts livestock mobility is more conditioned by cyclical environmental patterns than by dynamics of uncertainty, while in others the reverse may be true. Pastoral systems cannot be assumed to be unpredictable, and the presence of some unpredictability at certain scales or according to certain metrics does not denote the absence of regular patterns. In the Tajikistan case, there is some temporal unpredictability, but this does not change the fact that the system is mostly characterized by clear patterns. When seeking to understand or advocate for the need for livestock mobility, it is not always accurate to invoke uncertainty, and doing so superfluously or exaggeratedly may in fact work against the end goals of such advocacy work by erroneously making pastoralists' land management priorities seem erratic and unamenable to legal protections. Diagnoses of uncertainty should always be empiric and never dogmatic.

\section{Principles for pastoral land governance Flexibility in access rules is not a required precondition for mobility}

As described earlier, the term "flexibility" has been invoked to describe both mobility patterns as well as institutional structures and social and spatial boundaries. Here we are focussed on flexibility in this latter sense of access rules. Flexible or "fuzzy" access rules have been identified as important for facilitating livestock mobility better than clear rules or fixed boundaries (e.g. Lane and Moorehead 1994; Fernández-Giménez 2002 ; Bassett 2009; Mwangi and Ostrom 2009; Butt 2016; Davies et al. 2016). However, there are two ways that stable access rules can maintain mobility. Firstly, it is possible that spatial or social boundaries are so large or inclusive that they can remain firm without ever being "crossed", even when livestock are highly mobile. Secondly, and more important to the current point, when territorial boundaries do need to be crossed, it is the substance of the access rules rather than their stability that determines whether or not they facilitate mobility. Indeed, dependable boundaries and access rules can facilitate mobility.

For over a century, legal scholars have understood property as a "bundle" of many different rights, which can be combined in diverse ways. This metaphor reflects how "ownership interests can be divided over time[...] and among different people, as in the case of concurrent interests[...]and common interest communities" (Baron 2013, 58). With

\footnotetext{
${ }^{8}$ Though focusing most on flexibility, Fernández-Giménez (2002) also frames secure use rights as threatening to mobility and reciprocity.
}

respect to property rights over natural resources, these rights can include many incarnations of rights of access, withdrawal, management, exclusion, or alienation (Schlager and Ostrom 1992). Rights can only exist when they are protected by corresponding duties (Schlager and Ostrom 1992), and the "bundle" metaphor is also variously rendered as a bundle "rights and duties" or "rights and obligations". This fuller view of property relations - rather than a caricatured view of all property rights solely as fee simple absolute ownershipmakes clear that well-defined rights are not antithetical to mobility.

Non-possessory property rights for access (rights to enter an area) and withdrawal (rights to take something from an area) can be given to individuals or groups with specifications for which manners and timing of use are permissible. More comprehensive possessory property interests-more akin to what may be commonly thought of as "ownership", often including rights of exclusion or alienation in addition to management-can be bound with certain duties, such as an obligation to maintain a certain land use or allow other parties periodic access. A property arrangement, in sum, can be stable and secure without being absolute ownership.

Both governmental and non-governmental systems of rules and norms can produce and maintain secure and predictable property relations. The relative suitability, relevance, and authority of one system over another is context-specific (Von Benda-Beckmann 1997), but governmental law is often qualitatively different due to its symbolic stature and coercive power (Merry 1988). Examples of secure non-governmental property relations that facilitate livestock mobility include persistent agreements between farmers and herders that allow for post-harvest grazing on crop residues or even, as Moritz (2016) argues, reliable open access to certain common-pool resources as facilitated by duties of reciprocity. In formal codified law, there are examples such as government-owned livestock migration routes and accompanying livestock resting points, as are found in Tajikistan, or public lands whose grazing rights can be leased.

Servitudes are another important instrument of formal codified law that can facilitate mobility with clear, dependable rules. Fragmentation of rangelands into privatized parcels belonging to a patchwork of owners has rightly been identified as a threat to livestock mobility (see Galvin et al. 2008 and Galvin 2009 for many examples), but privatization, individualization, and disaggregation of pasture areas are not insurmountable obstacles to livestock mobility. Servitudes-a long-standing class of agreement that includes easements, covenants, and profits à prendre-can grant certain land rights to parties other than the possessor and also restrict or direct the possessor's management of the land and do so in a way 
that endures even as properties change hands, "[giving] stability to property arrangements over both time and space" (Rose 2011, 297). Servitudes can prevent fragmentation of use rights and grazable land cover-types of fragmentation that can threaten livestock mobilityeven in the face of fragmentation of ownership.

In Rasht district, customary arrangements have arisen that function like servitudes. Every village's spring and fall pastures are actually aggregations of individual households' private fodder-growing plots. While these are treated as individualized plots for the summer months of fodder growing and harvest, in the spring and fall, the owners open these areas up for grazing the animals that belong to any other resident of their village.

Secure dependable property relations can include a wide array of potential conditions, restrictions, and extents of rights to cater to a given context. For example, a group could have a clear, inalienable, and heritable right to graze up to 1000 head of small-stock in a certain area for up to 90 days a year between June 1 and October 1 as long as it does not cut any trees down or prevent transit of other herds. The person who possesses title to that land might not be allowed to develop or cultivate the areas used for grazing.

Property rights can be partial and circumscribed without being flexible, and it is the distribution of specific use and access rights that can facilitate livestock mobility and grazing in multiple noncontiguous areas. In contexts where the spatiotemporal patterns of relative forage abundance are highly unpredictable, then mobility patterns themselves must be flexible. In this case, such fixed access rules may not work, and emphasis should be put on fixed processes for negotiating access or resolving disputes (Niamir-Fuller and Turner 1999), but as this paper has shown, this is not the norm and it must be understood that institutional flexibility is not a precondition for mobility.

\section{Pastoral land governance should be developed by looking for predictability, and efforts to maintain flexibility in access rules should be judicious and well-justified}

Flexibility in pastoral land use and governance can have costs. It is difficult to implement (Niamir-Fuller and Turner 1999), can make land tenure insecure and resource access less reliable (Fernández-Giménez 2002), and is difficult to design governance systems for (Brottem et al. 2014). It may at times help pastoralists cope with environmental uncertainty, but it also introduces "knowledge uncertainty" which can confound management efforts by making the actions of others difficult to predict (Meinzen-Dick and Pradhan 2002, 14; Ostrom
1990). Maintaining regular spatial patterns of livestock movement can lead to longer and perhaps more cooperative relationships with other land users (McAllister et al. 2006).

Because of these costs, flexibility should only be advocated to the extent that it is necessary from a livelihood standpoint; it should not be embraced as an immutable and inherent quality of all pastoral settings. Neither mobility nor flexibility are ends unto themselves. In this paper, I have explained that mobility is a response to variability over time in the spatial distribution of pastoral resources, while flexibility is a response to especially unpredictable variability. As clarified in the "Flexibility in access rules is not a required precondition for mobility" section, mobility alone is not a sufficient justification for flexible access rules and boundaries. Even where unpredictable environmental variability necessitates flexible mobility and access rules, pastoralists can be understood as "primarily reliability seeking" (Roe et al. 1998, 387). So that those of us advocating for pastoralists are not unwittingly introducing needless obstacles to pasture access and governance, the presence and importance of unpredictable variability should be empirically assessed rather than assumed.

In short, pastoral land governance should be developed by looking for predictability. The patterns uncovered can then form the basis for creating secure tenure arrangements. To be clear, I am not advocating for a presumption of stability or predictability but rather arguing against a presumption of unpredictability. In practice, there will inevitably be certain parameters that are more predictable and other parameters that are less predictable; in the process of identifying patterns in some parameters that influence livestock mobility, you will also end up recognizing those areas of persistent uncertainty that need to be accommodated. The approaches to find these patterns will be context-specific, and a set methodology for doing so is outside of the scope of this paper. In almost every context, the pastoralists themselves will likely be the single most important source for identifying patterns.

Because the scale of observation will affect assessments of predictability (Brottem et al. 2014), it should be assessed at multiple scales that are meaningful for the dynamics of the given system, including the scale of the entire area or region that a pastoral group uses over the course of several years. Assessments of important parameters at multiple scales may also uncover the scales at which certain parameters display sufficient regularity to suggest a particular land governance arrangement. That is, in looking for predictability, we may find the right blend of spatial scales and types of rules to best serve pastoralists. 


\section{Conclusion}

This paper clarified two pairs of bedrock concepts that we use to talk about pastoral systems: variability and unpredictability and mobility and flexibility. Variability and mobility are inherent to all pastoral systems, but it is just a subset of these where dynamics of unpredictability and flexibility are significant. In many contexts, the distinctions between these terms are subtle and difficult to parse. In the mountain pastoralism system of Tajikistan presented here, however, the differences are stark. Here, livestock mobility is an essential response to the highly pronounced spatiotemporal variability of forage availability. The spatiotemporal variability in this system is conditioned by distinct seasons and altitudinal zonation-temporal and spatial patterns that are regular across years. As a result, the mobility patterns themselves do not require much flexibility beyond minor adjustments in timing of movements to respond to slight variations in the onset of assured seasonal changes.

By clarifying the differences between these terms, we can then tie mobility to variability and flexibility to unpredictability. This allows us, as scholars and advocates for pastoralists, to characterize individual contexts more accurately and assess governance requirements without erroneously over-diagnosing unpredictability and overprescribing flexibility. Without question, some pastoral systems are uniquely characterized by unpredictable environmental conditions that require flexibility in both livestock mobility patterns and the land governance institutions that condition mobility patterns. However, this paper has shown that discussions of pastoralism-especially outside of academia-have exaggerated how often these characteristics are predominant. This paper also introduced three types of justifications for livestock mobility-completing the set, hedging bets, and diffusing pressure-to help describe the mobility needs in a given pastoral system. To avoid deleterious mischaracterizations of pastoral systems and to make management of pastoral resources more tractable, I proposed first looking for predictability and building from the reliable elements of the system rather than starting with an embrace of unpredictability and flexibility.

Putting this into practice is not a simple or obvious task, and the conceptual clarifications and calls for predictabilityfirst analysis are meant to provide a basis for further refinements. Future work is needed to articulate coherent methods for assessing unpredictability, including further investigation into the scale-dependence of notions of uncertainty (building from Brottem et al. 2014) and perhaps development of a method to assess how the relative desirability among multiple distinct grazing areas changes over time, as this is the precise type of variability that actually influences mobility. While this paper mentions several options for codified, nonpossessory land rights that appear theoretically compatible with the requirements of pastoral mobility, these are admittedly unproven and untested but deserve more scrutiny.

Regardless of whether these research directions are pursued further, this paper should at a minimum serve as a modest call for future scholarship on pastoralism: distinguish between unpredictable versus predictable variability and flexible versus predictable mobility patterns.

\begin{abstract}
Abbreviations
CV: Coefficient of variation; FAO: Food and Agriculture Organization of the United Nations; FGD: Focus group discussion; IFAD: International Fund for Agricultural Development; IUCN: International Union for Conservation of Nature and Natural Resources; NGO: Non-governmental organization; VSF: Vétérinaires Sans Frontières
\end{abstract}

\section{Acknowledgements}

The author thanks Matthew Turner, Erin Kitchell, and the reviewers for comments on earlier drafts of this paper.

\section{Author's contributions}

The author read and approved the final manuscript.

\section{Author's information}

KG is a PhD candidate in the Department of Geography at the University of Wisconsin-Madison. His research concerns land and resource governance, with a focus on pastoralists in Central Asia.

\section{Funding}

Fieldwork was supported by grants from the Fulbright US Student Program, the University of Wisconsin-Madison Department of Geography's Trewartha Graduate Research Award, and a US State Department Title VIII Research Scholar Fellowship awarded by American Councils for International Education. Writing was supported by a Mellon-Wisconsin Dissertation Writing Fellowship and a Whitbeck Dissertation Writing Fellowship from the UW-

Madison Department of Geography.

\section{Availability of data and materials}

The datasets generated and analysed during the current study are not publicly available due to limitations agreed to as part of the review of study protocols by the University of Wisconsin-Madison Institutional Review Board $(\mathrm{RBB})$, but some data are available from the corresponding author on reasonable request.

\section{Declarations}

Ethics approval and consent to participate

This study's protocols for obtaining consent and other ethics considerations were approved by the University of Wisconsin-Madison's Education and Social/Behavioral Science Institutional Review Board (study ID: 2016-0059).

Consent for publication

Not applicable.

\section{Competing interests}

The author declares that he has no competing interests.

Received: 5 April 2021 Accepted: 2 June 2021

Published online: 10 August 2021

\section{References}

Addison, Jane. 2016. The predictive value of resource defence theory in understanding resource user responses to climatic variability: Implications for the viability of institutions in a resource dependent context. Human Ecology 44 (2): 137-152. https://doi.org/10.1007/s10745-016-9810-4.

Adriansen, Hanne K. 2005. Pastoral mobility: A review. Nomadic Peoples 9 (1\&2): 207-215. https://doi.org/10.3167/082279405781826182.

Agrawal, Arun. 1999. Greener pastures: Politics, markets, and community among a migrant pastoral people. Durham: Duke University Press. 
Arbos, Philippe. 1923. The geography of pastoral life illustrated with European examples. Geographical Review 13 (4): 559-574. https://doi.org/10.2307/208164.

Augustine, David J. 2010. Spatial versus temporal variation in precipitation in a semiarid ecosystem. Landscape Ecology 25 (6): 913-925. https://doi.org/10.1 007/s10980-010-9469-y.

Balikchi, Asen. 1990. Tenure and transhumance: Stratification and pastoralism among the Lakenkhel. In The world of pastoralism: Herding systems in comparative perspective, ed. J. Galaty and D. Johnson. New York: Guilford Press.

Baron, Jane. 2013. Rescuing the bundle-of-rights metaphor in property law. University of Cincinnati Law Review 82 (1): 57-102

Barth, Fredrik. 1961. Nomads of South Persia: The Basseri tribe of the Khamseh Confederacy. Boston: Little, Brown and Company.

Bassett, Thomas J. 2009. Mobile pastoralism on the brink of land privatization in northern Côte d'Ivoire. Geoforum 40 (5): 756-766. https://doi.org/10.1016/j. geoforum.2009.04.005.

Behnke, Roy. 2000. Equilibrium and non-equilibrium models of livestock population dynamics in pastoral Africa: Their relevance to Arctic grazing systems. Rangifer 20 (2-3): 141-152. https://doi.org/10.7557/2.2 0.2-3.1509.

Brottem, Leif, Matthew Turner, Bilal Butt, and Aditya Singh. 2014. Biophysical variability and pastoral rights to resources: West African transhumance revisited. Human Ecology 42 (3): 351-365. https://doi.org/10.1007/s10745-0149640-1.

Butt, Bilal. 2016. Ecology, mobility and labour: Dynamic pastoral herd management in an uncertain world. Scientific and Technical Review of the Office International des Epizooties 35 (2): 461-472. https://doi.org/10.20506/ rst.35.2.2530

Casimir, Michael, and Aparna Rao. 1992. Mobility and territoriality: Social and spatial boundaries among foragers, fishers, pastoralists and peripatetics. Oxford: Berg.

Davies, Jonathan, et al. 2016. Governance of tenure technical guide 6: Improving governance of pastoral lands. Rome: FAO.

Davies, Jonathan, Claire Ogali, Lydia Slobodian, Guyo Roba, and Razingrim Ouedraogo. 2018. Crossing Boundaries: Legal and Policy Arrangements for Cross-Border Pastoralism. Rome: FAO and IUCN.

Davis, Diana. 2016. The arid lands: History, power, and knowledge. Cambridge: MIT Press. https://doi.org/10.7551/mitpress/10651.001.0001.

Ehlers, Eckart, and Hermann Kreutzmann. 2000. High mountain ecology and economy: Potential and constraints. In High Mountain Pastoralism in Northern Pakistan, ed. Eckart Ehlers and Hermann Kreutzmann. Stuttgart: Franz Steiner Verlag.

Elam, Yitzchak. 1979. Nomadism in Ankole as a substitute for rebellion. Africa 49 (2): 147-158. https://doi.org/10.2307/1158671.

Ensminger, Jean, and Andrew Rutten. 1991. The political economy of changing property rights: Dismantling a pastoral commons. American Ethnologist 18 (4): 683-699. https://doi.org/10.1525/ae.1991.18.4.02a00030.

Fernández-Giménez, Maria. 2002. Spatial and social boundaries and the paradox of pastoral land tenure: A case study from postsocialist Mongolia. Human Ecology 30 (1): 49-78. https://doi.org/10.1023/A:1014562913014.

Fernández-Giménez, Maria, Baival Batkhishig, Batjav Batbuyan, and Tungala Ulambayar. 2015. Lessons from the Dzud: Community-based rangeland management increases the adaptive capacity of Mongolian herders to winter disasters. World Development 68: 48-65.

Fernández-Giménez, Maria, and Sonya Le Febre. 2006. Mobility in pastoral systems: Dynamic flux or downward trend? International Journal of Sustainable Development and World Ecology 13 (5): 341-362. https://doi.org/1 0.1080/13504500609469685.

Galaty, John, and Douglas Johnson. 1990. The world of pastoralism: Herding systems in comparative perspective. New York: Guilford Press.

Galvin, Kathleen A. 2009. Transitions: Pastoralists living with change. Annual Review of Anthropology 38 (1): 185-198. https://doi.org/10.1146/annurev-a nthro-091908-164442.

Galvin, Kathleen, Robin Reid, Roy Behnke, and N. Thompson Hobbs, eds. 2008. Fragmentation in semi-arid and arid landscapes: Consequences for human and natural systems. Dordrecht: Springer. https://doi.org/10.1007/978-1-4020-4 906-4.

Gomarasca, Margherita, Cornelia Heine, and Andreas Jenet. 2016. Securing pastoralists' land rights. Rural 2150 (3): 30-31.

Guillet, David. 1983. Toward a cultural ecology of mountains: The central Andes and Himalaya compared. Current Anthropology 24 (5): 561-574. https://doi. org/10.1086/203061.
Herrera, Pedro, Jonathan Davies, and Pablo Manzano Baena. 2014. The governance of rangelands: Collective action for sustainable pastoralism. New York: Routledge. https://doi.org/10.4324/9781315768014.

Hobbs, N. Thompson, Kathleen Galvin, Chris Stokes, Jill Lackett, Andrew Ash, Randall Boone, Robin Reid, and Philip Thornton. 2008. Fragmentation of rangelands: Implications for humans animals and landscapes. Global Environmental Change 18 (4): 776-785. https://doi.org/10.1016/j.gloenvcha.2008.07.011

IFAD. 2020. How to prevent land use conflicts in pastoral areas. Rome: IFAD.

Hiernaux, Pierre. 2000. Implications of the 'new rangeland paradigm' for natural resource management. In The Sahel: Energy Supply, Economic Pillars of Rural Sahelian Communities, Need for Revised Development Strategies, eds. Hanne Adriansen, Anette Reenberg, and Ivan Nielsen. Copenhagen: SEREIN.

Illius, Andrew, and Timothy O'Connor. 1999. On the relevance of nonequilibrium concepts to arid and semiarid grazing systems. Ecological Applications 9 (3): 798-813. https://doi.org/10.1890/1051-0761(1999)009[0798:OTRONC]2.0.CO;2.

Ingold, Tim. 1980. Hunters, pastoralists, and ranchers: Reindeer economies and their transformations. Cambridge: Cambridge University Press. https://doi.org/10.1 017/CBO9780511558047.

Intigrinova, Tatyana. 2010. Social inequality and risk mitigation in the era of private land: Siberian pastoralists and land use change. Pastoralism: Research, Policy, and Practice 1(2): 178-197.

Kerven, Carol. 2004. The influence of cold temperatures and snowstorms on rangelands and livestock in northern Asia. In Rangelands at equilibrium and non-equilibrium: Recent developments in the debate around rangeland ecology and management, ed. Susanne Vetter. Cape Town: Programme for Land and Agrarian Studies.

Krätli, Saverio, and Nikolaus Schareika. 2010. Living off uncertainty: The intelligent animal production of dryland pastoralists. European Journal of Development Research 22 (5): 605-622. https://doi.org/10.1057/ejdr.2010.41.

Lane, Charles, and Richard Moorehead. 1994. New directions in rangeland resource tenure and policy. In In Living with uncertainty: New directions in pastoral development in Africa, ed. Ian Scoones. London: Intermediate Technology Publications Ltd.

León, Pérez, Octavio Bruzzone Natalia, and Marcos Easdale. 2020. A framework to tackle the synchrony between social and ecological phases of the annual cyclical movement of transhumant pastoralism. Sustainability 12 (8): 3462. https://doi.org/10.3390/su12083462.

Mahmudov, Mansur, Ghaffor Jüraev, and Bahrom Berdiev. 2012. Farhangi Güishho Janubii Zaboni Tojiki. Dushanbe: Pazhühishgohi Farhangi Forsi-Tojikii Saforati Jumhurii Islomi Eron dar Tojikiston.

Marin, Andrei. 2006. Confined and sustainable? A critique of recent pastoral policy for reindeer herding in Finnmark, Northern Norway. Nomadic Peoples 10 (2): 209-232. https://doi.org/10.3167/np.2006.100212.

McAllister, Ryan, lain Gordon, Marco Janssen, and Nick Abel. 2006. Pastoralist's responses to variation of rangeland resources in time and space. Ecological Applications 16 (2): 572-583. https://doi.org/10.1890/1051-0761(2006)01 6[0572:PRTVOR]2.0.CO;2

McCarthy, Nancy, and Monica Di Gregorio. 2007. Climate variability and flexibility in resource access: The case of pastoral mobility in Northern Kenya. Environment and Development Economics 12 (3): 403-421. https://doi.org/10.1 017/S1355770X07003609.

Meinzen-Dick, Ruth, and Rajendra Pradhan. 2002. Legal pluralism and dynamic property rights (CAPRi Working Paper No. 22). Washington, DC: International Food Policy Research Institute.

Merry, Sally E. 1988. Legal pluralism. Law and Society Review 22 (5): 869-896. https://doi.org/10.2307/3053638.

Moritz, Mark. 2016. Open property regimes. International Journal of the Commons 10 (2): 688-708. https://doi.org/10.18352/ijc.719.

Mehta, Lyla, Melissa Leach, Peter Newell, lan Scoones, K. Sivaramakrishnan, and Sally-Anne Way. 1999. Exploring understandings of institutions and uncertainty: New directions in natural resource management. IDS Discussion Paper 372. Brighton, UK: University of Sussex.

Moritz, Mark, Elizabeth Gardiner, Mark Hubbe, and Amber Johnson. 2019. Comparative study of pastoral property regimes in Africa offers no support tor economic defensibility model. Current Anthropology 60 (5): 609-636. https://doi.org/10.1086/705240.

Moritz, Mark, Paul Scholte, Ian Hamilton, and Saïdou Kari. 2013. Open access, open systems: Pastoral management of common-pool resources in the Chad Basin. Human Ecology 41 (3): 351-365. https://doi.org/10.1007/s10745-012-9550-z.

Mwangi, Esther, and Elinor Ostrom. 2009. Top-down solutions: Looking up from East Africa's rangelands. Environment 51 (1): 34-45. 
Netting, Robert. 1976. What Alpine peasants have in common: Observations on communal tenure in a Swiss village. Human Ecology 4 (2): 135-146. https:// doi.org/10.1007/BF01531217.

Neudert, Regina. 2015. Is individualized rangeland lease institutionally incompatible with mobile pastoralism? A case study from post-socialist Azerbaijan. Human Ecology 43 (6): 785-798. https://doi.org/10.1007/s10745-01 5-9792-7

Niamir-Fuller, Maryam, and Matthew Turner. 1999. A review of recent literature on pastoralism and transhumance in Africa. In Managing mobility in African rangelands: The legitimization of transhumance, ed. Maryam Niamir-Fuller. London: Intermediate Technology Publications. https://doi.org/10.3362/9781 780442761.002

Nori, Michele. 2019. Herding through uncertainties - regional perspectives: Exploring the interface of pastoralists and uncertainty. Results from a literature review. EUI Working Paper \#68. Florence: EUI.

Nozières, Marie-Odile, Charles-Henri Moulin, and Benoît Dedieu. 2011. The herd, a source of flexibility for livestock farming systems faced with uncertainties? Animal 5 (9): 1442-1457. https://doi.org/10.1017/\$1751731111000486.

Ostrom, Elinor. 1990. Governing the commons: The evolution of institutions for collective action. New York: Cambridge University Press. https://doi.org/10.101 7/CBO9780511807763.

Pappagallo, Linda, and Greta Semplici. 2020. Methodological mess: Doing research in contexts of high variability. Nomadic Peoples 24 (2): 179-194. https://doi.org/10.3197/np.2020.240201.

Pastoralist Knowledge Hub. 2020. Defining pastoralism and nomadic pastoralism. In Forum of the Pastoralist Knowledge Hub https://dgroups.org/fao/pastoralisthub/discussions/v2nw5899. Accessed 30 Nov 2020.

Peters, Pauline. 1987. Embedded systems and rooted models: The grazing lands of Botswana and the commons debate. In The question of the commons: The culture and ecology of communal resources, ed. Bonnie McCay and James Acheson. Tucson: The University of Arizona Press.

Rhoades, Robert, and Stephen Thompson. 1975. Adaptive strategies in alpine environments: Beyond ecological particularism. American Ethnologist 2 (3): 535-551. https://doi.org/10.1525/ae.1975.2.3.02a00110.

Robinson, Sarah, and E.J. Milner-Gulland. 2003. Contraction in livestock mobility resulting from state farm reorganization. In Prospects for pastoralism in Kazakstan and Turkmenistan: From state farms to private flocks, ed. Carol Kerven.

Roe, Emery, Lynn Huntsinger, and Keith Labnow. 1998. High-reliability pastoralism versus risk-averse pastoralism. Journal of Environment \& Development 7 (4): 387-421. https://doi.org/10.1177/107049659800700404.

Rose, Carol. 2011. Servitudes. In Research handbook on the economics of property law, ed. Kenneth Ayotte and Henry Smith. Cheltenham: Edward Elgar Publishing.

Rota, A., Saverio Krätli, Michele Nori, Alban Bellinguez, Marco Bassi, and Oliver Mundy. 2018. How to do note: Engaging with pastoralists - a holistic development approach. Rome: IFAD.

Schlager, Edda, and Elinor Ostrom. 1992. Property-rights regimes and natural resources: A conceptual analysis. Land Economics 68 (3): 249-262. https://doi. org/10.2307/3146375

Scoones, lan. 1992. Coping with drought: Responses of herders and livestock in contrasting savannah environments in southern Zimbabwe. Human Ecology 20 (3): 293-314. https://doi.org/10.1007/BF00889899.

Scoones, lan. 1994. New directions in pastoral development in Africa. In In Living with uncertainty: New directions in pastoral development in Africa, ed. lan Scoones. London: Intermediate Technology Publications Ltd. https://doi.org/1 0.1080/096145249100077821.

Scoones, lan, and Andy Stirling. 2020. Uncertainty and the politics of transformation. In The politics of uncertainty: Challenges of transformation, ed. Ian Scoones and Andy Stirling. New York: Routledge. https://doi.org/1 0.4324/9781003023845-1.

Starrs, Paul. 2018. Transhumance as antidote for modern sedentary stock raising. Rangeland Ecology \& Management 71 (5): 592-602. https://doi.org/10.1016/j.ra ma.2018.04.011.

Steimann, Bernd. 2012. Conflicting strategies for contested resources: Pastoralists' responses to uncertainty in post-socialist rural Kyrgyzstan. In Pastoral practices in High Asia, ed. Hermann Kreutzmann. Berlin: Springer. https://doi.org/10.1 007/978-94-007-3846-1_8.

Sullivan, Sian, and Rick Rohde. 2002. On non-equilibrium in arid and semi-arid grazing systems. Journal of Biogeography 29 (12): 1595-1618. https://doi.org/1 0.1046/j.1365-2699.2002.00799.x.
Swallow, B.M., and N. McCarthy. 2000. Property rights, risk, and livestock development in Africa: Issues and project approach. In Property Rights, Risk, and Livestock Development in Africa, ed. N. McCarthy, B.M. Swallow, M. Kirk, and P. Hazell.

Swift, Jeremy. 1994. Dynamic ecological systems and the administration of pastoral development. In Living with uncertainty: New directions in pastoral development in Africa, ed. Ian Scoones. London: Intermediate Technology Publications Ltd.

Tapper, Richard. 1979. Individuated grazing rights and social organization among the Shahsevan nomads of Azerbaijan. In Pastoral Production and Society. Cambridge: Cambridge University Press.

Turner, Matthew. 2011. The new pastoral paradigm: Engaging the realities of property institutions and livestock mobility in dryland Africa. Society and Natural Resources 24 (5): 469-484. https://doi.org/10.1080/08941920903236291.

Turner, Matthew, John McPeak, Kramer Gillin, Erin Kitchell, and Niwaeli Kimambo. 2016. Reconciling flexibility and tenure security for pastoral resources: The geography of transhumance networks in eastern Senegal. Human Ecology 44 (2): 199-215. https://doi.org/10.1007/s10745-016-9812-2.

Turner, Matthew, and Eva Schlecht. 2019. Livestock mobility in sub-Saharan Africa: A critical review. Pastoralism: Research, Policy, and Practice 9 (13): 1-15.

Van Belle, Gerald. 2008. Statistical Rules of Thumb. Hoboken: Wiley.

Vetter, Susanne. 2005. Rangelands at equilibrium and non-equilibrium: recent developments in the debate. Journal of Arid Environments 62 (2): 321-341. https://doi.org/10.1016/j.jaridenv.2004.11.015.

Von Benda-Beckmann, Franz. 1997. Citizens, strangers and indigenous peoples: Conceptual politics and legal pluralism. Law \& Anthropology 9: 1-42.

Walsh, Rory, and Damian Lawler. 1981. Rainfall seasonality: Description, spatial patterns and change through time. Weather 36 (7): 201-208. https://doi.org/1 0.1002/j.1477-8696.1981.tb05400.x.

Williams, Mark, and Vladimir Konovalov. 2008. Central Asia temperature and precipitation data, 1879-2003, Version 1. Boulder: National Snow and Ice Data Center (NSIDC). https://doi.org/10.7265/N5NK3BZ8 Accessed 13 Aug 2015.

\section{Publisher's Note}

Springer Nature remains neutral with regard to jurisdictional claims in published maps and institutional affiliations.

\section{Submit your manuscript to a SpringerOpen ${ }^{\circ}$ journal and benefit from:}

- Convenient online submission

- Rigorous peer review

- Open access: articles freely available online

High visibility within the field

- Retaining the copyright to your article

Submit your next manuscript at $>$ springeropen.com 